\title{
Evaluation of the Use of Burkolderia Caribensis Bacteria for the Reduction of Phosphorus Content in Iron Ore Particles
}

\author{
Leonardo Martins da Silva ${ }^{a *}$ (1), Ellen Cristine Giese ${ }^{b}$ (), Giulio Antunes de Medeiros ${ }^{a}$, \\ Marcio Teodoro Fernandes ${ }^{a}$, José Adilson de Castro ${ }^{a}$ () \\ ${ }^{a}$ Universidade Federal Fluminense, Av. dos Trabalhadores 420, Vila Sta. Cecília, 27255-125, \\ Volta Redonda, RJ, Brasil. \\ ${ }^{B}$ Centro de Tecnologia Mineral, Avenida Pedro Calmon, 900, Cidade Universitária, 21941-908, \\ Rio de Janeiro, RJ, Brasil.
}

Received: August 24, 2021; Accepted: January 13, 2022

\begin{abstract}
With the growing industrialization, there is a constant increase in the world demand for iron ore, thus implying an increase in the volume of mining, resulting in the extraction of ores with higher levels of silicon, phosphorus and sulfur impurities. Therefore, it is highly relevant to use beneficiation techniques that allow the use of iron ores with high levels of impurities, and it is known that a widely used alternative is to perform a pre-treatment of iron ore particles in order to reach the limit of acceptable phosphorus before application in steel production. Therefore, this study aims to evaluate the pre-treatment process of iron ore particles aiming at reducing the phosphorus content using the bacterial strain burkolderia caribensis in contaminated iron ore samples. Through the rotatable central composite design technique, it was possible to evaluate the best conditions for the use of the bacterial strain to reduce the phosphorus content in the particles. The results indicated that the developed process has relevant applicability. The results contribute to a better understanding of the use of the bacterial strain as a pretreatment process to reduce the phosphorus content of iron ore particles and also to the development of new cleaner technologies.
\end{abstract}

Keywords: Microwave, Leaching, Reduction of phosphorus, Iron ore.

\section{Introduction}

With the worldwide growth in demand for iron ore, the volume of mining has been steadily increasing, resulting in the extraction of ores with a low concentration of iron and higher impurities. In order to increase the iron content in low-grade ore, concentration technologies have been used, making it possible to mine deposits with lower iron content and higher contaminants, including phosphorus.

In this sense, the literature has reported works developing some methods for removing phosphorus in iron ores involving smelting, separation by physical processes and chemical leaching processes, among others ${ }^{1-10}$. The smelting process was considered effective for dephosphorization, but at a very high cost, and further investigations about the process and its optimization are still needed. In the process of physical separation, the ores must be crushed and comminuted until the phosphorus is dissociated from the iron minerals and then dephosphorized with separation by flotation or magnetic separators.

However, due to the low levels of extraction of the phosphorus element, the high cost of the grinding process and the losses of iron that occur in the process, this method was considered unfeasible for the extraction of the phosphorus element. However, the chemical approach, in which the ore is leached with an appropriate solution, is

*e-mail: leonardouffsilva@gmail.com a relatively simple process, as it can directly treat the ore particles without strict comminution requirements. Some results from the literature ${ }^{11-15}$ indicated that dephosphoration through acid leaching is feasible, however, depending on the leaching environment, it can become an extremely relevant environmental problem.

An alternative to reduce the content of the phosphorus element in contaminated ores is the reuse of the generated waste, thus contributing to minimize the costs of extraction and classification of minable ores. However, it is important to note that the way in which a given impurity occurs in an ore is associated with the formation of that deposit, which can be presented in combined particles of complex phases that are difficult to remove by conventional processes of comminution and separation. In iron ores from non-weathered deposits, the primary source of phosphorus is apatite ${ }^{6}$.

In weathered iron ore deposits, phosphorus occurs highly disseminated in the form of secondary minerals. However, in some cases, the element phosphorus can be found in the iron ore particles complexed with the goethite molecules, $\mathrm{FeO}(\mathrm{OH})$, in the form of a solid solution ${ }^{12}$ as shown in Figure 1.

Although there are chemical processes designed to reduce the phosphorus content of iron ores, the historical low prices of this commodity make all of these alternatives unfeasible. Biotechnology can be an economical and environmentally 


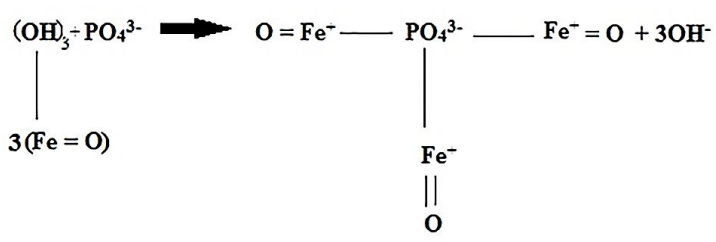

Figure 1. Mechanism of phosphorus occurrence in goethite.

friendly way to overcome this problem. Works by Buis ${ }^{4}$ and Parks et al. ${ }^{16}$ dealt with the use of fungi strains with high phosphate solubilization activity to treat phosphate iron ores, however, the main disadvantage of these investigations was that the strains used were not associated with the ore being treated. When artificially inoculated in a given environment, indigenous microorganisms, as a general rule, compete for the best adaptation in terms of causing less distortion than exogenous microorganisms. Therefore, if an efficient biobeneficiation process is to be implemented for the treatment of a certain mineral raw material, studies on the microbiota living naturally on such substrate and evaluation of its desired properties should be the initial step.

According to Priha et al. ${ }^{17}$, the potential to obtain higher yields of phosphorus reduction at an economic level can make the bioleaching processes economically attractive for the reduction of phosphorus in the industry. In addition, materials containing high levels of phosphorus are considered waste and their reuse can potentially be implemented, thus contributing to reduce the environmental footprint in mining. This could be a way of alleviating the predicted future situation where the physical limitations of the resource will become increasingly important.

\subsection{Possible solubilization and biosorption mechanisms}

Biotechnology has been used for decades to develop new technologies for waste treatment and removal of minerals of interest. Bioleaching of chalcopyrite concentrate was developed and evaluated at commercial scale in 1995. Further work is in progress for use of the archaea to bioleach lower grade chalcopyrite ore in engineered heaps.

Phosphate-solubilizing bacteria can supply plants with phosphorus from sources that are otherwise poorly available. Therefore, solubilization of phosphatic minerals by microorganisms is a research topic of significant interest to the agriculture sector due to its applicability in biofertilization. Moreover, such a feature could also be economically and environmentally useful for emerging industries like biomining.

The most common mechanism used by microorganisms for solubilizing calcium phosphates seems to be the acidification of the medium via biosynthesis and release of a wide array of organic acids ${ }^{18-20}$. Gluconic acid is the principal organic acid produced by most soil bacteria, including Burkholderia spp, although other organic acids are also generated by different phosphate bioleching bacteria ${ }^{18,19}$.

Direct oxidation of glucose to gluconic acid generates a transmembrane proton motive force that may be used for bioenergetic and/or membrane transport functions while the dissociable proton of gluconic acid is available for phosphate solubilization $^{20,21}$. In addition to gluconic and acetic acids, others organic acids may be produced by these two bacterial strains. However, taking in consideration that gluconic acid is among the strongest naturally occurring organic acids known and it has historically been associated with bacteria selected for extremely high levels of phosphate solubilization ${ }^{20}$, it is likely that the phosphate solubilization activity of $\mathrm{B}$. caribensis FeG103 and B. ferrariae FeG101 mainly relies on the production of gluconic acid. However, more research is needed to gain a better insight into the mechanism underlying the phosphate solubilizing capability of B. ferrariae Fe.

According to Vijayaraghavan et al. ${ }^{21}$, batch experiments usually focus on the study of factors influencing biosorption, which are important in the evaluation of the full biosorption potential of any biomaterial. Important factors include solution $\mathrm{pH}$, temperature, ionic strength, biosorbent dosage, biosorbent size, initial solute concentration, agitation rate, etc. The solution $\mathrm{pH}$ usually plays a major role in biosorption, and seems to affect the solution chemistry of metals/dyes and the activity of the functional groups of the biomass.

Therefore, in this work, the route to reduce phosphorus content through bacterial attack will be evaluated using the bacterial strain Burkholderia Caribensis. The influence of parameters such as contact time, ore mass and volume of the bacterial medium was studied.

\section{Materials and Methods}

\subsection{Growth of the burkolderia caribensis bacterial strain}

The isolation of the strain used in the phosphate removal experiments from the ore was as described by Delvasto et al..$^{22}$. A phosphorus-free, chemically-defined liquid culture medium, based on the NBRIP medium of Nautiyal ${ }^{23}$, was used in the phosphate-removal experiments. The composition of the medium was as described in Table 1 (in $\mathrm{g} / 1$ deionized water). The medium was sterilized by autoclaving at $121^{\circ} \mathrm{C}$ for $30 \mathrm{~min}$. The $\mathrm{pH}$ of the medium was around 5.0 after sterilization.

After bacterial growth, different iron ore amounts were added to different volume values of the liquid medium containing the bacterial strain where it was possible to evaluate the best conditions for reducing the phosphorus content in the iron ore samples, which occurs in function of the consumption of the element phosphorus by the bacterial strain contained in the liquid medium.

\subsection{Characterization of the iron ore samples}

$\mathrm{X}$-ray diffraction (XRD) and scanning electron microscopy (SEM) were performed for the characterization of samples.

The samples of iron ore were originated in the Quadrilátero Ferrifero region of Minas Gerais, Brazil. All samples were comminuted in a bar mill at the facilities of the Mineral Technology Center - CETEM, generating particle size fractions smaller than $0.234 \mathrm{~mm}$.

The obtained samples were submitted in the powder form to X-ray diffraction analyses using the Rietveld method in parallel to scanning electron microscopy. The X-ray diffraction technique using the Rietveld method is based on 
Table 1. Composition of the medium used for growth of the burkolderia caribensis bacteria strain.

\begin{tabular}{ccc}
\hline Compound & Chemical Formula & Composition (g/l) \\
\hline Glucose & $\mathrm{C}_{6} \mathrm{H}_{12} \mathrm{O}_{6}$ & 10.0 \\
\hline $\begin{array}{c}\text { Magnesium } \\
\text { chloride } \\
\text { hexahydrate }\end{array}$ & $\mathrm{MgCl}_{2}, 6 \mathrm{H}_{2} \mathrm{O}$ & 5.0 \\
\hline $\begin{array}{c}\text { Magnesium sulfate } \\
\text { heptahydrate }\end{array}$ & $\mathrm{MgSO}_{4}, 7 \mathrm{H}_{2} \mathrm{O}$ & 0.25 \\
\hline Potassium chloride & $\mathrm{KCl}$ & 0.20 \\
\hline Ammonium sulfate & $\left(\mathrm{NH}_{4}\right)_{2} \mathrm{SO}_{4}$ & 0.10 \\
\hline
\end{tabular}

the simulation of an entire diffractive profile starting from structural parameters of the component phases, allowing more information to be extracted from the diffractograms. The Rietveld method takes into account the overlap of the peaks of all the phases present and the contributions of the background noise. Hematite, Quartz and Goethite were the main phases identified by the X-ray diffraction method, where the absence of apatite and aluminosilicate compounds was observed.

Figure 2 shows the X-ray diffraction spectrum of the iron ore used in this investigation and Table 2 shows the mineralogical composition of the iron ore sample.

The chemical analysis was carried out using the inductively coupled plasma optical emission spectrometry method performed at CETEM. The phosphorus content in the ore sample was $346 \mathrm{mg} / \mathrm{kg}$, corresponding to $0.0346 \% \mathrm{wt}$. Scanning electron microscopy analyses were carried out at Universidade Federal Fluminense - UFF.

For analysis of the acid baking-leaching process, a volume of $300 \mathrm{~mL}$ of water was used, which was added to a $500 \mathrm{~mL}$ beaker that served as a reactor. The particles were agitated using an IKA mechanical stirrer model RW20. After the reaction time was over, the mixture was vacuum filtered on a Büchner funnel and taken to the oven for drying at $40^{\circ} \mathrm{C}$ for 1 hour. All the samples were then sent for quantitative analysis of the phosphorus content, where the ultraviolet radiation emission in the visible spectrum (UV-VIS) measurement technique was used. The calculation of the removal percentage was as follows:

$\%=\frac{C_{f}-C_{i}}{C_{i}} \times 100$

Where $C_{f}$ is the final concentration of the phosphorus element after the leaching process and $C_{i}$ is the initial concentration of the phosphorus element prior to the leaching process.

\subsection{Statistical evaluation of the process}

Using experimental planning based on statistical principles, researchers can extract from the system under study as much useful information as possible by doing a minimum number of experiments, applying, for example, the factorials $2^{\mathrm{k}}$ or $2^{\mathrm{k}-\mathrm{p}}$. For a better analysis of response surfaces, the centered face cube design can be used. The DCC is a design that was developed with the objective of making it possible to find the point of maximum or minimum response, in tests with $\mathrm{k}$ factors, each with five levels, and with a number of points
Table 2. Mineralogical composition of the iron ore sample (\% by mass fraction).

\begin{tabular}{ccc}
\hline Mineral & Chemical Formula & Mass Fraction, \% \\
\hline Hematite & $\left(\mathrm{Fe}_{2} \mathrm{O}_{3}\right)(1)$ & 72.89 \\
\hline Kaolinite & {$\left[\mathrm{Al}_{2} \mathrm{Si}_{2} \mathrm{O}_{5}(\mathrm{OH})_{4}\right](2)$} & 4.64 \\
\hline Quartz & $\left(\mathrm{SiO}_{2}\right)(3)$ & 12.05 \\
\hline Gibbsite & {$\left[\mathrm{Al}(\mathrm{OH})_{3}\right](4)$} & 3.18 \\
\hline Goethite & {$[\mathrm{FeO}(\mathrm{OH})](5)$} & 7.25 \\
\hline
\end{tabular}

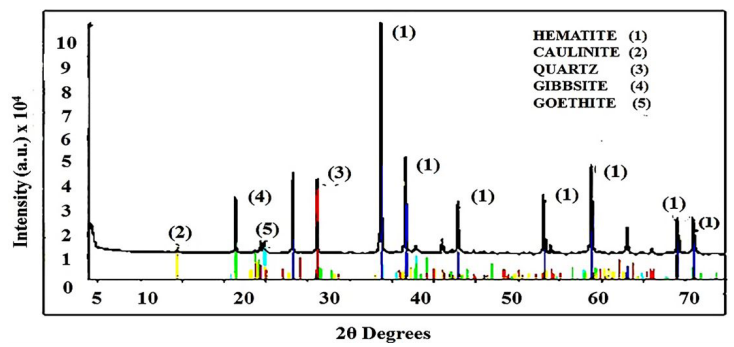

Figure 2. X-ray diffraction spectrum of the iron ore sample.

lower than other types of designs used, for example, the $3^{k}$ factorial. However, when it comes to the total of stationary points, using the parametric test for difference of proportion, the proportions of maximum in each interval of experimental coefficient were found to be significantly different, mainly in relation to the rotational DCC, that is, the rotational DCC always obtained a greater number of experiments in which the maximum points were between levels -1 and 1 .

Among the standard designs, the Central Composite Design (DCC) is considered an optimal design. According to Atkinson and Donev ${ }^{24}$ the composite designs belong to a family of efficient designs, which require few tests for their performance. As for efficiency measures, Donev and Atkinson ${ }^{24}$ and Lucas ${ }^{25}$ show that the DCC behaves well according to some of the main optimization criteria. In addition, it has interesting characteristics for the search for the point that gives the optimal response, which are the smaller number of treatments in relation to the complete factorials and the possibility to be performed sequentially, in order to move towards the optimization of the system, that is, through the execution of a part of the experiment (applying $2^{\mathrm{k}}$ factorial experiments or first order fraction-experiment) through the "steepest ascent technique".

Table 3 presents the values used in the factorial planning within each experimental coefficient range and also within the levels $(-1,1)$, and outside these levels.

The values presented in Table 3 were stipulated considering the mean between the upper and lower axial values.

\section{Results and Discussion}

\subsection{Reduction of phosphorus content using the bacterial strain burkolderia caribensis}

In order to evaluate the effects of the variables iron ore mass, time of contact with the bacterial strain and volume of the bacterial medium in contact with the ore on the reduction 
of the phosphorus content in the iron ore particles, the tests results showed in Table 4 were presented in the graph from Figure 3.

Figure 3 is shows the results of the phosphorus removal tests using the burkolderia caribensis strain.

Figure 3 shows the results of the phosphorus removal tests where it was possible to observe that the highest percentage of reduction obtained was for the sample containing $2 \mathrm{~g}$ of iron ore using $50 \mathrm{ml}$ of the bacterial volume in $12 \mathrm{~h}$ of contact of the bacterial strain with the iron ore sample. However, small values of reduction of the phosphorus

Table 3. Levels used in the factorial planning.

\begin{tabular}{lccccc}
\hline Variables & -1.41 & -1 & 0 & 1 & +1.41 \\
\hline Time (h) & 0.5 & 6 & 12 & 18 & 24 \\
\hline $\begin{array}{c}\text { Iron ore } \\
\text { mass (g) }\end{array}$ & 2 & 14 & 26 & 38 & 50 \\
\hline $\begin{array}{c}\text { Volume } \\
\text { of } \\
\text { bacterial } \\
\text { medium } \\
(\mathrm{ml})\end{array}$ & 10 & 30 & 50 & 75 & 100 \\
\hline
\end{tabular}

Table 4. Levels used in factorial planning and phosphorus removal results.

\begin{tabular}{ccccc}
\hline Test & $\begin{array}{c}\text { Time } \\
(\mathrm{h})\end{array}$ & $\begin{array}{c}\text { Iron ore mass } \\
(\mathrm{g})\end{array}$ & $\begin{array}{c}\text { Volume of } \\
\text { bacterial } \\
\text { medium }(\mathrm{ml})\end{array}$ & $\begin{array}{c}\text { Phosphorus } \\
\text { Removal (\%) }\end{array}$ \\
\hline 1 & 6 & 14 & 30 & 0.557 \\
\hline 2 & 6 & 14 & 75 & 0.696 \\
\hline 3 & 18 & 14 & 30 & 0.161 \\
\hline 4 & 18 & 14 & 75 & 0.510 \\
\hline 5 & 6 & 38 & 30 & 0.006 \\
\hline 6 & 6 & 38 & 75 & 0.034 \\
\hline 7 & 18 & 38 & 30 & 0.047 \\
\hline 8 & 18 & 38 & 75 & 0.034 \\
\hline 9 & 12 & 26 & 10 & 0.002 \\
\hline 10 & 12 & 26 & 100 & 0.155 \\
\hline 11 & 0,5 & 26 & 50 & 0.161 \\
\hline 12 & 24 & 26 & 50 & 0.016 \\
\hline 13 & 12 & 2 & 50 & 1.950 \\
\hline 14 & 12 & 50 & 50 & 0.008 \\
\hline 15 & 12 & 26 & 50 & 0.016 \\
\hline
\end{tabular}

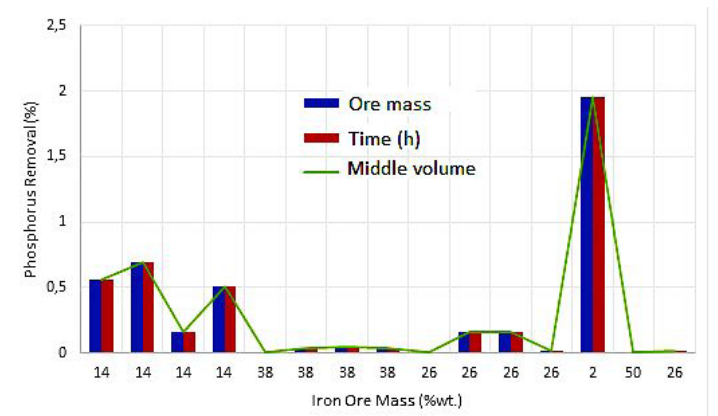

Figure 3. Results of the phosphorus removal tests using the burkolderia caribensis strain. content were observed in the iron ore particles. According to Santos et al. ${ }^{26}$, it is considered that bioleaching occurs by two different mechanisms: (i) direct, where the bacteria bind to the mineral surface and produces a series of compounds that separate sulfur-metal and sulfur-sulfur bonds; (ii) indirect, where bacteria oxidize Fe (II) to Fe (III) and use electrons in their metabolic processes. As noted in this work, the alternative (i) is considered, being generated by the bacterial strain acidic substances that by hydrogenation break bonds between the elements.

However, according to Figure 1, where the complex of goethite and phosphorus was presented, one can conjecture that in addition to the action of acids formed by bacterial involvement, it is necessary to apply additional energy to disrupt this structure and release the complexed phosphorus element demonstrated by the low values of solubilization rate and reduction in phosphorus content performed by the bacterial strain, being shown in Figure 3.

\subsection{Reduction of the phosphorus content in the iron ore particles as a function of the variables iron ore mass, time and volume of the bacterial medium}

In Figure 4, the rate of phosphorus removal from the iron ore particles is presented as a function of the iron ore mass and time of contact with the iron ore sample.

It was possible to observe that higher values of reduction of the phosphorus content occurred for smaller values of mass of iron ore during the entire interval of time. The lower values of mass of ore suggest a greater value of contact between bacterial strain and particles of iron ore suggesting that the reduction in phosphorus content is due to the greater contact of bacteria with the iron ore particles. Going with the previous statement Silva et al. ${ }^{27}$ in the work titled "evaluation of the diffusional coefficient in the acid baking process using microwave energy to reduce phosphorus content in iron ore particles", through the values of phosphorus reduction rate, it was possible to demonstrate the control steps of the phosphorus reduction process and to observe that the chemical control steps on the particle surface, together with the diffusional control step with the diffusion of the leaching agent into the particle, are the steps that determine the rate of phosphorus

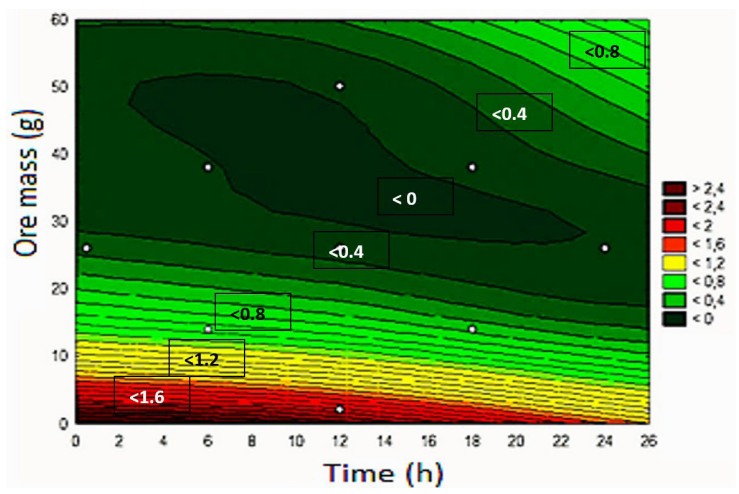

Figure 4. Contour plot of the response surface for phosphorus reduction of iron ore particles as a function of iron ore mass and time of contact with the sample. 
removal on the particles of the iron ore. Thus, it is possible to consider the mixed control model as the model that best represents the rate of reduction of phosphorus content in iron ore particles using microwave energy as a heating source.

According to Delvasto et al. ${ }^{22}$, the understanding of biogeochemical mechanisms involved in the removal of phosphate from iron ore is extremely important because the bacterial/mineral interactions are complex and the phosphorus extraction process can be adversely affected by dynamic chemical processes, such as re-precipitation of iron and phosphate in a biofilm microenvironment. Most bacteria, including leaching bacteria, grow on mineral surfaces and form multispecies biofilms. It has been shown that when the substrate surface area is not limiting, $\mathrm{N} 80 \%$ of the inoculum disappears from the solution in $24 \mathrm{~h}$, forming a biofilm ${ }^{28-30}$. However, some cells also remain in the planktonic stage ${ }^{29}$. Non-contact bioleaching is carried out by planktonic bacteria, which oxidizes ions in solution, while the contact mechanism of bioleaching occurs at the interface between the bacterial cell and the surface mineral ${ }^{31}$.

According to the results presented by Ishii et al. ${ }^{31}$ and the detailed procedures provided by Bennett et al. ${ }^{32}$, strongly adhesive bacterial interactions to surfaces, as those promoted by proteinrich appendages, are less prone to disruptions during CPD procedures. In any case, distribution density of the observed extracelular networks ought not to be strongly affected by sample preparation and, thus, the difference in relative density and cross-linking of the extracellular networks found in the biofilms formed by B. caribensis FeGL03 on iron ore particles may be regarded as representative of each condition tested.

Figure 5 shows the phosphorus reduction profile of the iron ore particles as a function of the iron ore mass and the volume of the liquid medium of the bacterial strain.

It was observed that higher values of reduction of phosphorus content occurred in lower values of mass of iron ore and in higher values of volume of liquid medium of the bacterial strain. The lower values of ore mass and large values of bacterial strain volume suggest a dependence on the contact between bacterial strain and iron ore particles as also shown in Figure 3.

Due to the nature of the cellular components, several functional groups are present on the bacterial cell wall, including carboxyl, phosphonate, amine and hydroxyl groups $s^{33,34}$. As they are negatively charged and abundantly available, carboxyl groups actively participate in the binding of metal cations. Several dye molecules, which exist as dye cations in solutions, are also attracted towards carboxyl and other negatively charged groups. Golab et al. ${ }^{35}$ indicated that the carboxyl groups of the cell wall peptidoglycan of Streptomyces pilosus were responsible for the binding of copper. Also, amine groups are very effective at removing metal ions, as it not only chelates cationic metal ions, but also adsorbs anionic metal species or dyes via electrostatic interaction or hydrogen bonding. Vijayaraghavan and Yun $^{36}$ confirmed that the amine groups of C. glutamicum were responsible for the binding of reactive dye anions via electrostatic attraction. In general, increasing the $\mathrm{pH}$ increases the overall negative charge on the surface of cells until all the relevant functional groups are deprotonated ${ }^{37}$.
Figure 6 shows the rate of reduction of phosphorus of the iron ore particles as a function of the contact time and the volume of the liquid medium of the bacterial strain.

Higher values of reduction of the phosphorus content occurred in intermediate values of time and volume of the liquid medium of the bacterial strain. The absence of variation in time and in the concentration of the liquid medium containing the bacterial strain demonstrates the dependence of the mass of ore in reducing the phosphorus content using the bacterial strain. Such dependence is evidenced by the action of acids formed by the bacterial strain on the iron ore particles. According to Delvasto et al. ${ }^{22}$ cultures of B. ferrariae FeG101 and B. caribensis FeG103, produced concentrations of acetic acid in the medium showing increasing values of such acids as the incubation time increased. The presence of citric acid in the medium was also tested. Although citric acid is another organic acid known to be commonly produced by phosphate solubilizing bacteria, it was not detected in the cultures of B. ferrariae FeG101 and B. caribensis FeG103 by the analytical technique used. The most common mechanism used by microorganisms to solubilize calcium phosphates appears to be acidification of the medium via biosynthesis and release of a wide range of organic acids ${ }^{18-20}$.

Gram-negative bacteria exhibiting superior mineral phosphate solubilization capabilities use the direct oxidase

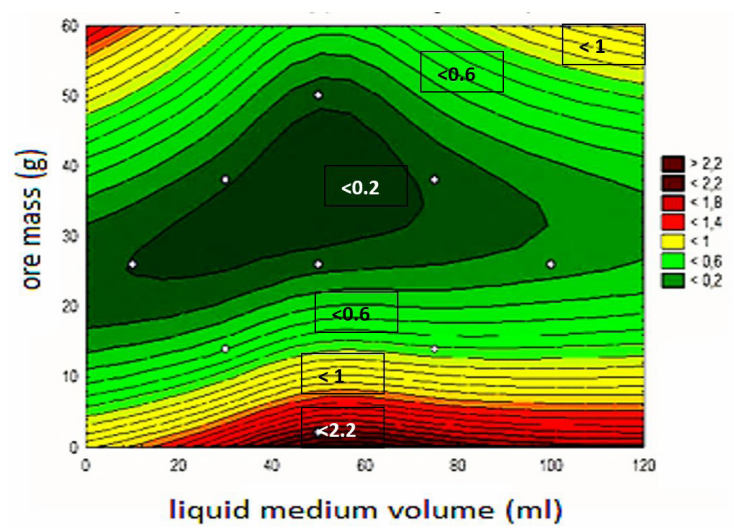

Figure 5. Contour plot of the response surface for phosphorus reduction of iron ore particles as a function of the mass of ore and the volume of the liquid medium of the bacterial strain.

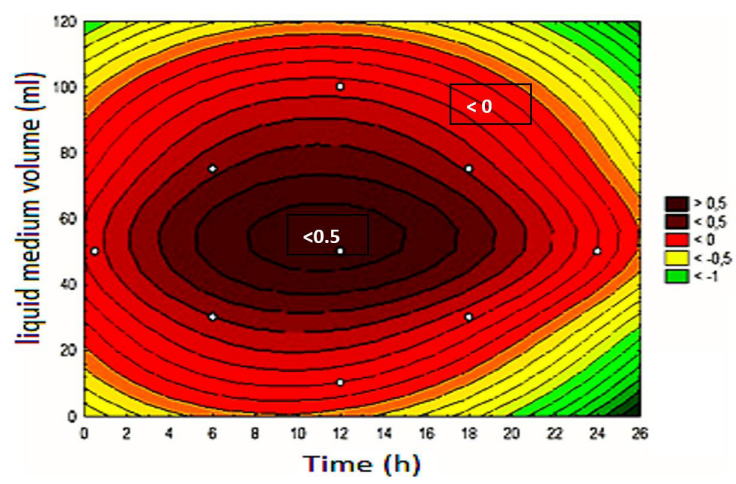

Figure 6. Contour plot of the response surface for phosphorus reduction of iron ore particles as a function of contact time and volume of the liquid medium of the bacterial strain. 

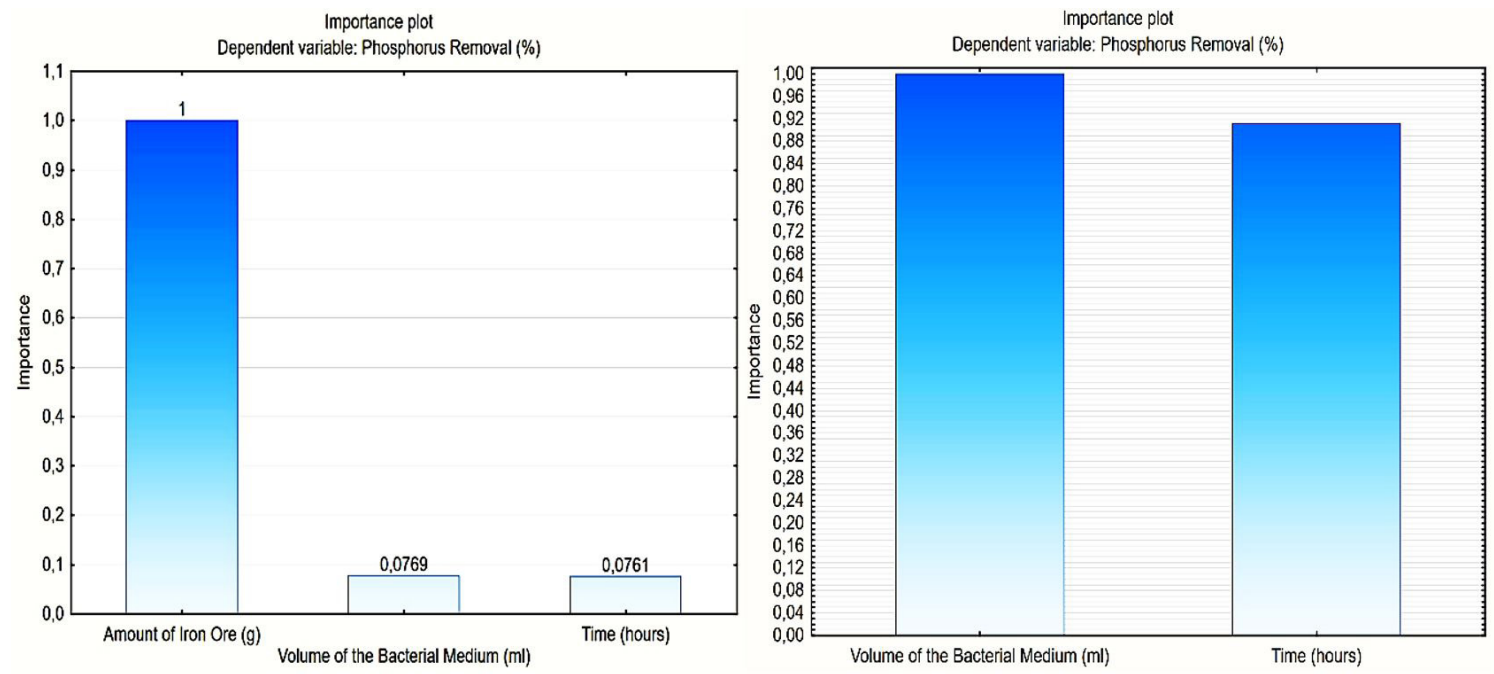

Figure 7. Importance plot of the variables evaluated on the reduction of the phosphorus content of the iron ore samples.

pathway (also known as non-phosphorylating oxidation), in which gluconic acid is produced from glucose. The direct oxidation of glucose to gluconic acid generates a driving force for transmembrane protons that can be used for bioenergetics and /or membrane transport functions, while the dissociable proton from gluconic acid is available for phosphate solubilization ${ }^{20,38}$.

Heterotrophic bacteria solubilize inorganic phosphorus through the production of organic acids, such as gluconic acid, acetic acid, oxalic acid, citric acid, lactic acid and itaconic acid ${ }^{39}$. The chelating ability of organic acids is important, e.g. Kim et al. ${ }^{39}$ showed that organic acids can be more effective in solubilizing phosphorus than inorganic acids at the same $\mathrm{pH}$.

Strains of the Pseudomonas, Bacillus and Rhizobium genera are among the most powerful solubilizing phosphates ${ }^{19,40}$ but also other heterotrophic bacterial genera and species have been shown to have phosphorus solubilization capacity, such as Burkholderia spp., Clavibacter xyli, Enterobacter agglomerans, Serratia and Streptomyces ${ }^{22,40-42}$.

Figure 7 shows the importance plot of the independent variables on the level of reduction in the phosphorus content of the iron ore samples.

In Figure 7, it was observed that for the reduction of the phosphorus element in iron ore samples using the bacterial strain burkolderia caribensis, the iron ore mass is highly relevant followed by the volume of the bacterial strain and the contact time between the strain and the iron ore particles. Thus, it was observed that the percentage of iron lost decreased with the increase in the concentration of ore solids. Thus, it was possible to observe that the way in which the ore is in the structure hinders the release of the phosphorus element followed by the reduction of the phosphorus content by the bacterial strain. However, the benefits of using biotechnology regarding the use of the bacterial strain in the hydrometallurgical process must be considered and the process must be better developed. Going to meet Biomining, reported that the use of microorganisms to recover metals by oxidative dissolution of metal sulfide minerals in primary ores and wastes (tailings, rock dumps etc.) is now well established as a global technology ${ }^{43}$. Conventionally, biomining uses irrigated systems (rock dumps and bioheaps; principally for recovering base metals) or stirred tanks, which are mostly used for recovering gold from refractory ores. In both of these, the microbial catalysts of mineral oxidation, chiefly acidophilic chemolithotrophic bacteria and archaea, occur in juxtaposition to the metal sulfides, often growing as biofilms on the minerals themselves where they mediate contact leaching ${ }^{44}$.

\section{Conclusion}

In order to evaluate the profile of the removal of the phosphorus element from iron ore samples, as well as the advantages inherent to the use of the burkolderia caribensis strain as leaching agent, a statistical modeling was elaborated, evaluating the best conditions for the reduction of the phosphorus content in the iron ore particles during the leaching stage. Thus, the following conclusions were drawn:

- Through the values demonstrated by the statistical evaluation it was possible to conclude that higher values of reduction of the phosphorus content using the bacterial strain burkolderia caribensis were found for lower values of mass of iron ore samples.

- Through the values shown by the phosphorus reduction profile of iron ore particles indicating higher reduction levels for lower iron ore mass values, it was possible to conclude that higher reduction values occur due to the greater contact between bacterial strain and the iron ore particles. It was also possible to conclude that greater values of reduction of the phosphorus content occurred due to lower values of ore mass in large volume of the bacterial strain, emphasizing the dependence of the contact between bacterial strain and the iron ore particles, with the phosphorus being released by the organic acid generated by the bacterial strain as presented by the previous conclusion. 
- It was possible to conclude through the values of the phosphorus reduction profile of the iron ore particles as a function of the contact time and the volume of the liquid medium of the bacterial strain that greater values of reduction of the phosphorus content occurred in intermediate values of time and volume of the liquid medium of the bacterial strain, indicating the strong dependence of the mass of the iron ore sample in the process of reduction of the phosphorus content using the bacterial strain burkolderia caribensis.

- It was possible to conclude through the statistical plot of importance of the variables evaluated on the reduction of the phosphorus content of the iron ore samples that the ore mass variable was the most important variable in the process of removal of phosphorus content using the bacterial strain burkolderia caribensis followed by the variables volume of the bacterial liquid medium and the contact time of the bacterial strain in the iron ore particles and although the action of organic acids produced by the bacterial strain collaborates to reduce the phosphorus content in the particles, it is necessary to apply additional energy to disrupt the structure of the phosphate complex and release the complexed phosphorus element.

\section{Acknowledgments}

The authors thank the funding agencies: Coordination of Improvement of Higher Education Personnel, (CAPES). Ministry of Science and Technology. They also thank the Metallurgical Engineering graduate program of the Fluminense Federal University for the scientific technical support.

\section{References}

1. Graham J. Phosphorous in the iron ore from the Hamersley iron formations. Proc Australas Inst Min Metall. 1973;246:41-2.

2. Gooden JEA, Walker WM, Allen RJ. A chemical process fordephosphorisation of iron ore. In: National Chemical Engineering Conference; 1979; Barton, ACT. Proceedings. Barton: Institution of Engineers; 1979; p. 21-33.

3. Peixoto G. Improvement of the reduction process in P content and other gangues in iron ore and its agglomerates. International patent No. 93/10271. Pergamon Press Ltd.; 1991. 1202 p.

4. Buis P. Bioremediation techniques for the removal of phosphorus from iron ore [PhD dissertation]. USA: Michigan Technological University; 1995.

5. Cheng CY, Misra VN, Clough J, Mun R. Dephosphorisation of western australian iron ore by hydrometallurgical process. Miner Eng. 1999;12(9):1083-92.

6. Young-Shin J, Tao J, Yang Y, Qian L, Guang-Hui L, Yu-Feng G. Removal of phosphorus from iron ores by chemical leaching. Changsha: School of Minerals Processing and Bioengineering, Central South University; 2006.

7. Nunes APL. Flotação de fosfatos presentes em minérios de ferro brasileiros [dissertação]. Belo Horizonte: Curso de Pósgraduação em Engenharia Metalúrgica e de Minas, Universidade Federal de Minas Gerais; 2009.

8. Carvalho BC. Aproveitamento de minérios de ferro de baixo teor: tendências, tecnologias utilizadas e influências no sequenciamento de lavra [dissertação]. Ouro Preto: Programa de Pós-graduação em Engenharia Mineral, Universidade Federal de Ouro Preto; 2012.

9. Silva LM, Nascimento M, Castro JA, Mota IO. Avaliação da utilização da energia de micro-ondas para o processo da remoção de fósforo contido no minério de ferro. Holos. 2014;3:245-55.

10. Mamdouh OAB, Timo FA, Mattila R. Thermally assisted liberation of high phosphorus oolitic iron ore: a comparison between microwave and conventional furnaces. Powder Technol. 2015;269(5):7-14.

11. Forssberg R, Asolfsson G. Dephosphorisation of high-phosphorus iron ores by means of acid leaching. Erzmetal. 1981;34:316-22.

12. Dukino R. Phosphorus in Hamersley Range iron ore. USA: BHP Internal Report; 1997.

13. Kui L, Qiyuan C, Zhoulan Y, Huiping H, Zhiying D. Kinetics of leaching of a Chinese laterite containing maghemite and magnetite in sulfuric acid solutions. Changsha: School of Chemistry and Chemical Engineering, Central South University; 2012.

14. Xia WT, Ren Z, Gao YF. Removal of phosphorus from high phosphorus iron ores by selective $\mathrm{HCl}$ leaching method. Chongqing: School of Metallurgical and Materials Engineering, Chongqing University of Science and Technology; 2013.

15. Silva LM, Nascimento M, Castro JA, Mota IO. Avaliação da utilização da energia de micro-ondas para o processo da remoção de fósforo contido no minério de ferro. Holos. 2014;3:245-55.

16. Parks E, Olson G, Brinckman F, Baldi F. Characterization by high performance liquid chromatography (HPLC) of the solubilization of phosphorus in iron ore by a fungus. J Ind Microbiol. 1990;5(2-3):183-90.

17. Priha O, Sarlin T, Blomberg P, Wendling L, Mäkinen J, Arnold $\mathrm{M}$, et al. Bioleaching phosphorus from fluorapatites with acidophilic bacteria. Hydrometallurgy. 2014;150:269-75.

18. Igual JM, Valverde A, Cervantes E, Velázquez E. Phosphatesolubilizing bacteria as inoculants for agriculture: use of updated molecular techniques in their study. Agronomie. 2001;21(6-7):561-8.

19. Rodríguez H, Fraga R. Phosphate solubilizing bacteria and their role in plant growth promotion. Biotechnol Adv. 1999;17(45):319-39.

20. Goldstein AH, Krishnaraj PU. Phosphate solubilizing microorganisms vs. phosphate mobilizing microorganisms: what separates a phenotype from a trait? In: Velázquez E, Rodríguez-Barrueco C, editors. First International Meeting on Microbial Phosphate Solubilization. Dordrecht: Springer; 2007. p. 203-13.

21. Vijayaraghavan K, Yun Y-S. Bacterial biosorbents and biosorption. Biotechnol Adv. 2008;26(3):266-91.

22. Delvasto P, Valverde A, Ballester A, Igual JM, Muñoz JA, González F, et al. Characterization of brushite as a re-crystallization product formed during bacterial solubilization of hydroxyapatite in batch cultures. Soil Biol Biochem. 2006;38(9):2645-54.

23. Nautiyal C. An efficient microbiological growth medium for screening phosphate solubilizing microorganisms. FEMS Microbiol Lett. 1999;170(1):265-70.

24. Atkinson AC, Donev AN. Optimum experimental designs. Oxford: Clarendon Press; 1992. (Oxford Statistical Science Series; 8)

25. Lucas JM. Which response surface design is best. Technometrics. 1976;18(4):411-7.

26. Santos SCC, Alviano DS, Alviano CS, Pádula M, Leitão AC, Martins OB, et al. Characterization of Gordonia sp. strain F.5.25.8 capable of dibenzothiophene desulfurization and carbazole utilization. Appl Microbiol Biotechnol. 2006;71(3):355-62.

27. Silva LM, Nascimento M, Oliveira EM, Queiroz AV, Fernandes MT, Castro JA. Evaluation of the diffusional coefficient in the acid baking process using microwave energy to reduce phosphorus content in iron ore particles. Volta Redonda: Universidade Federal Fluminense; 2020. 
28. Bagdigian RM, Myerson AS. The adsorption of Thiobacillus ferrooxidans on coal surfaces. Biotechnol Bioeng. 1986;28(4):467-79.

29. Dispirito AA, Dugan PR, Tuovinen OH. Sorption of Thiobacillus ferrooxidans to particulate material. Biotechnol Bioeng. 1983;25(4):1163-8.

30. Gehrke T, Telegdi J, Thierry D, Sand W. Importance of extracellular polymeric substances from Thiobacillus ferrooxidans for bioleaching. Appl Environ Microbiol. 1998;64(7):2743-7.

31. Rohwerder T, Gehrke T, Kinzler K, Sand W. Bioleaching review part A: progress in bioleaching: fundamentals and mechanisms of bacterial metal sulfide oxidation. Appl Microbiol Biotechnol. 2003;63(3):239-48.

32. Ishii S, Koki J, Unno H, Hori K. Two morphological types of cell appendages on a strongly adhesive bacterium, Acinetobacter sp. strain Tol 5. Appl Environ Microbiol. 2004;70(8):5026-9.

33. Doyle RJ, Matthews TH, Streips UN. Chemical basis for selectivity of metal ions by the Bacillus subtilis cell wall. J Bacteriol. 1980;143(1):471-80.

34. Van Der Wal A, Norde W, Zehnder AJB, Lyklema J. Determination of the total charge in the cell walls of gram-positive bacteria. Colloids Surf B Biointerfaces. 1997;9(1-2):81-100.

35. Golab Z, Breitenbach M, Jezierski A. Sites of copper binding in Streptomyces pilosus. Water Air Soil Pollut. 1995;82(3-4):713-21.

36. Vijayaraghavan K, Yun Y-S. Utilization of fermentation waste (Corynebacterium glutamicum) for biosorption of Reactive Black 5 from aqueous solution. J Hazard Mater. 2007b;141(1):45-52.

37. Lin TF, Huang HI, Shen FT, Young CC. The protons of gluconic acid are the major factor responsible for the dissolution of tricalcium phosphate by Burkholderia cepacia CC-A174. Bioresour Technol. 2006;97(7):957-60.

38. Khan MS, Zaidi A, Wani PA. Role of phosphate solubilizing microorganisms in sustainable agriculture: a review. In: Lichtfouse E, Navarrete M, Debaeke P, Véronique S, Alberola C, editors. Sustainable agriculture. Dordrecht: Springer; 2009. p. 551-70.

39. Kim KY, McDonald GA, Jordan D. Solubilization of hydroxyapatite by Enterobacter agglomerans and cloned Escherichia coli in culture medium. Biol Fertil Soils. 1997;24(4):347-52.

40. Postma J, Nijhuis EH, Someus E. Selection of phosphorus solubilizing bacteria with biocontrol potential for growth in phosphorus rich animal bone charcoal. Appl Soil Ecol. 2010;46(3):464-9.

41. Illmer P, Schinner F. Solubilization of inorganic phosphates by microorganisms isolated from forest soil. Soil Biol Biochem. 1992;24(4):389-95.

42. Johnson DB. Biomining: biotechnologies for extracting and recovering metals from ores and waste materials. Curr Opin Biotechnol. 2014;30:24-31.

43. Harrison STL. Biotechnologies that utilize acidophiles. In: Quatrini R, Johnson DB, editors. Acidophiles: life in extremely acidic environments. Haverhill: Caistor Academic Press; 2016. pp. 265-83.

44. Bellenberg S, Diaz M, Noel N, Sand W, Vera M. Biofilm formation, communication and interactions of leaching bacteria during colonization of pyrite and sulfur surfaces. Res Microbiol. 2014;165:773-81. 